\title{
MAKROEKONOMICZNE DETERMINANTY RYZYKA KREDYTOWEGO W POLSCE ZE SZCZEGÓLNYM UWZGLĘDNIENIEM KURSÓW WALUT OBCYCH
}

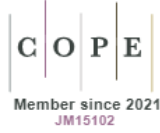

\section{Anna Pluskota* \\ MACROECONOMIC DETERMINANTS OF CREDIT RISK IN POLAND, WITH PARTICULAR CONCERNING EXCHANGE RATES}

\begin{abstract}
The purpose of the article. The aim of the study is to show the impact of the key macroeconomic determinants of the credit risk of the banking sector in Poland in 2011-2020. This aim was achieved by analysis of the Pearson correlation coefficient and econometric models allowing to determine the impact of individual variables on the NPL index.

Methodology: The empirical part includes the presentation and description of basic descriptive statistics, as well as the calculation of the Pearson correlation coefficient with the interpretation of the obtained results. The dynamic econometric model describing the variability of the NPL ratio was built using mainly macroeconomic variables.

Results of the research: Research has shown the impact of changes in the unemployment rate and the inflation rate on credit risk. On the other hand, the impact of economic growth on the NPL ratio in the analyzed period was not statistically significant. The relationship between credit risk and changes in foreign exchange rates (CHF, USD, EUR) turned out to be negative in the analyzed period, which means that the increases in exchange rates of these currencies did not result in a significant burden of credit risk in the banking sector in Poland.
\end{abstract}

Keywords: credit risk, determinants of credit risk, exchange rates.

JEL Class: C22, G21, G32.

*Mgr, Wydział Ekonomiczno-Socjologiczny, Uniwersytet Łódzki, e-mail: anna.pluskota@uni.lodz.pl. 


\section{WSTĘP}

Determinanty ryzyka kredytowego można zasadniczo podzielić na mikroekonomiczne i makroekonomiczne, przy czym w literaturze szczególnie są analizowane czynniki mikroekonomiczne, np. dynamika kredytów czy stosunek aktywów do kapitału. W szczególności niewiele przeprowadzono do tej pory badań empirycznych weryfikujących oddziaływanie zmiennych makroekonomicznych na ryzyko kredytowe w Polsce.

Ryzyko kredytowe jest głównym i najważniejszym rodzajem ryzyka w sektorze bankowym w Polsce, a zarządzaniu tym ryzykiem poświęca się najwięcej uwagi w bankowości. Dlatego szczególnie istotne jest prowadzenie badań nad zrozumieniem mechanizmów gospodarczych stymulujących wielkość tego ryzyka w całym sektorze. W szczególności brakuje analiz poświęconych oddziaływaniu zmiany głównych walut obcych na ryzyko kredytowe w ostatnich latach. Liczne spory sądowe w przypadku kredytów powiązanych z kursem franka szwajcarskiego skłaniają do przeprowadzenia pogłębionej analizy oddziaływania zmienności kursu CHF/PLN, ale także innych kursów, na badane ryzyko.

Poniższe badanie zostało przeprowadzone w celu zweryfikowania wpływu wybranych zmiennych makroekonomicznych na ryzyko kredytowe w Polsce w okresie 1.2011-2.2020, ze szczególnym uwzględnieniem oddziaływania kursu CHF/PLN, USD/PLN i EUR/PLN na ryzyko kredytowe. W badaniu empirycznym zweryfikowano dwie hipotezy badawcze. Pierwsza hipoteza badawcza jest następująca: Wzrost kursu franka szwajcarskiego nie zwiększył ryzyka kredytowego w Polsce. Natomiast druga hipoteza badawcza to: Wzrost kursu dolara i euro nie zwiększyły ryzyka kredytowego w Polsce. Badanie obejmuje przygotowanie danych kwartalnych poprzez od sezonowanie zgromadzonych szeregów czasowych. Następnie przeprowadzono analizę statystyczną i ekonometryczną za pomocą estymacji KMNK. Kluczowe wnioski z przeprowadzonych badań wskazują, że kursy głównych walut obcych (franka szwajcarskiego, dolara i euro) w analizowanym okresie nie obciążyły ryzyka kredytowego w sektorze bankowym w Polsce. W analizowanym okresie zmiany wartości kursów walut obcych nie były tak gwałtowne jak w poprzedniej dekadzie (w szczególności w latach 2008-2009). Zmniejszające się wolumeny kredytów mieszkaniowych w CHF z roku na rok (w badanym okresie), mimo wahań kursu CHF/PLN, pozwalają na wnioskowanie, że Kredytobiorcy na ogół regulują swoje zobowiązania (Raport KNF z 06.2020 r.: 40). 


\section{PRZEGLĄD LITERATURY}

Dokonując przeglądu literatury można zauważyć dużą różnorodność czynników makroekonomicznych oddziałujących na ryzyko kredytowe. Część tych determinant jest specyficznych dla danego obszaru gospodarczego lub kraju, część zaś wydaje się być uniwersalna i ponadczasowa. Dlatego też w poniższej części przedstawiono te determinanty, które są adekwatne dla gospodarki Polski i w literaturze potwierdzono istotny ich wpływ na ryzyko kredytowe sektora bankowego.

Jako szczególnie istotną publikację w zakresie determinant ryzyka kredytowego mierzonego wskaźnikiem NPL (non-performing loans - kredyty zagrożone utratą wartości) można wskazać badanie (Klein, 2013), które potwierdziło kluczową rolę czynników makroekonomicznych w kształtowaniu się ryzyka kredytowego w sektorze bankowym. Klein wskazał m.in. na następujące zmienne makroekonomiczne oddziałujące na wartość wskaźnika NPL: wzrost realnego PKB, stopę bezrobocia, poziom inflacji i kursy walut obcych. Ujemny wpływ dynamiki realnego PKB na NPL został potwierdzony również w szeregu innych badań (Nkusu, 2011; Castro, 2013: 672-683). Zależność ta ma jednoznacznie ujemną relację, ponieważ wzrost gospodarczy sprzyja terminowemu spłacaniu zobowiązań, co przekłada się bezpośrednio na mniejszy poziom kredytów zagrożonych utratą wartości. Jeśli miernik ten rośnie, powoduje zwiększenie się dobrobytu społeczeństwa i jednostek gospodarczych, a więc i ogólne poprawia się zdolność do terminowego spłacania posiadanych zobowiązań kredytowych.

Kolejną zmienną makroekonomiczną oddziałującą w sposób istotny na ryzyko kredytowe jest zmiana stopy bezrobocia (Sztaudynger, 2018: 155-177). Zależność między tymi zmiennymi jest dodatnia, ponieważ wzrost bezrobocia będzie prowadził do wzrostu niespłacanych kredytów i większego ryzyka kredytowego sektora bankowego. Zdolność kredytowa konsumentów opiera się głównie na płynności dochodów pozyskiwanych z pracy, zatem utrata możliwości zarobkowania w dłuższym okresie będzie skutkować utratą możliwości bieżącego regulowania zobowiązań. Jako główny czynnik wpływający na sytuację kredytową konsumenta $\mathrm{w}$ literaturze podawane są właśnie wynagrodzenia (Breeden i Thomas, 2008: 11-44).

Wpływ inflacji na ryzyko kredytowe okazuje się być niejednoznaczny, ponieważ relacja ta może być dodatnia lub ujemna w zależności od pozostałych warunków makroekonomicznych gospodarki. Dodatni wpływ poziomu inflacji na NPL wykazali m.in. Ćurak et al. (2013: 45-53). Poziom inflacji wskazuje na to, czy w danej gospodarce ceny są stabilne, czy też ulegają dynamicznym zmianom. Pewien niski poziom inflacji jest określany jako korzystny dla gospodarki, ponieważ sprzyja wzrostowi gospodarczemu, a więc ta mała inflacja będzie sprzyjać także terminowemu spłacaniu zobowiązań kredytowych. Jednakże w przypadku 
dużej niestabilności cen dochodzi do szeregu procesów gospodarczych, które oddziałują na zdolność do terminowego spłacania zobowiązań. Wysoka inflacja powoduje z jednej strony obniżenie wartości realnej zadłużenia, lecz z drugiej strony prowadzi także do obniżenia realnej wartości dochodów konsumentów, a więc obniża zdolność regulowania zobowiązań kredytowych. Wysoki poziom inflacji może jednak nie mieć tak negatywnych skutków dla ryzyka kredytowego, jeśli towarzyszy mu dynamiczny wzrost płac, a co za tym idzie realne dochody konsumentów nie ulegają obniżeniu na skutek procesów inflacyjnych.

Kursy walut obcych oddziałują na ryzyko kredytowe, ponieważ wpływają na wartość zadłużenia i wysokość rat kredytów walutowych (Beck et al., 2013). Wzrost kursu walutowego powoduje zwiększenie wartości zadłużenia w tej walucie w przeliczeniu na walutę krajową. Czynnik kursu waluty obcej szczególnie istotnie oddziałuje na ryzyko kredytowe w państwach o dużej skali kredytów walutowych w całym portfelu kredytów. Wpływ kursu franka szwajcarskiego na ryzyko kredytowe polskiego sektora bankowego był zbadany m.in. przez Wdowińskiego (2014: 55-77), gdzie wykazano istotny statystycznie wpływ wzrostu kursu CHF/PLN na NPL w okresie od I kwartału 1997 r. do II kwartału 2013 r. Zgodnie z tymi badaniami wzrostu kursu franka szwajcarskiego obciążył ryzyko kredytowe. Część badaczy jednak wskazuje na możliwość spadku wskaźnika NPL w wyniku wzrostu kursu waluty obcej. Ta ujemna relacja może wynikać z dużej konkurencyjności dóbr krajowych w stosunku do dóbr zagranicznych (Zeman i Jurca, 2008: 1-26) i poprawy sytuacji finansowej eksporterów.

Zagadnienie wpływu waluty obcej na ryzyko kredytowe jest szczególnie istotne $\mathrm{w}$ Polsce $\mathrm{w}$ ostatnich latach, ponieważ 27,9\% wartości bilansowej brutto portfela kredytów mieszkaniowych stanowią kredyty walutowe, z czego aż 22,7\% to kredyty z kapitałem wyrażonym w CHF (Raport KNF z 06.2020 r.: 41). Wysokość rat kredytów walutowych (rat wyrażonych w PLN) jest uzależniona m.in. od parametrów ulegających zmianie w trakcie trwania umowy kredytowej, czyli kursu waluty obcej i stawki referencyjnej (dla CHF najczęściej jest to stawka LIBOR 3M dla CHF). W warunkach stabilnej sytuacji ekonomicznej zmiany w zakresie kursu walut obcych były rekompensowane przez zmiany w wysokości stawki referencyjnej, przez co ogólna wartość rat kredytów nie podlegała gwałtownym zmianom. W latach 2008-2009 jednak doszło do znacznej aprecjacji kursu CHF/PLN, która to nie została zrekompensowana przez równomierny spadek stawki referencyjnej, co skutkowało gwałtownym wzrostem rat kredytów walutowych w CHF. W późniejszym okresie także dochodziło do znacznych wzrostów kursu CHF/PLN, m.in. w styczniu 2015 r. Wydarzenia te oraz wprowadzenie w życie tzw. „Rekomendacji S” spowodowały wstrzymanie sprzedaży kredytów hipotecznych w walutach obcych. Aktualnie wg raportu Komisji Nadzoru Finansowego wartość kredytów w CHF z roku na rok ulega sukcesywnemu zmniejsze- 
niu (Raport KNF z 06.2020 r.: 40). Zatem powstaje pytanie, czy w ostatniej dekadzie zmienność kursów walut obcych wpłynęła istotnie na ryzyko kredytowe sektora bankowego w Polsce. Postawiono następujące hipotezy badawcze:

H1: Wzrost kursu franka szwajcarskiego nie zwiększył ryzyka kredytowego w Polsce.

H2: Wzrost kursu dolara i euro nie zwiększyły ryzyka kredytowego w Polsce.

Powyższe hipotezy badawcze zostały zweryfikowane na podstawie analizy statystyczno-ekonometrycznej przedstawionej w kolejnej części pracy.

\section{DANE I METODY BADAWCZE}

Weryfikacja postawionych hipotez badawczych została dokonana za pomoca narzędzi statystycznych (analiza podstawowych statystyk opisowych i współczynników korelacji Pearsona) i ekonometrycznych przy użyciu KMNK (Klasycznej Metody Najmniejszych Kwadratów), a ogólny model ma następującą postać:

gdzie:

$$
N P L_{t}=\alpha_{t}+\beta_{t} N P L_{t-1}+\gamma_{t} B_{t}+\mu_{t}
$$

$\alpha_{t}-$ wyraz wolny,

$N P L_{t-1}$ - zmienna zależna opóźniona o 1 kwartał,

$B_{t}-$ zmienna niezależna,

$\mu_{t}-$ składnik losowy.

Przedstawiona hipoteza badawcza została zweryfikowana przy użyciu analizy statystycznej i ekonometrycznej zebranych danych finansowych o częstotliwości kwartalnej za okres od 1.2011 r. do 2.2020 r. Lista analizowanych w badaniu danych finansowych jest następująca:

- NPL (źródło: KNF) - wskaźnik kredytów zagrożonych będących odpowiednikiem miary ryzyka kredytowego. Wskaźnik został obliczony jako iloraz należności zagrożonych i należności ogółem.

- Kredyty (źródło: KNF) - wartość kredytów i pożyczek udzielonych dla sektora finansowego (m.in. Bank Centralny, instytucje depozytowo-kredytowe, towarzystwa ubezpieczeniowe i reasekuracyjne, poza bankowe instytucje finansowe, GPW, biura maklerskie) wycenione wg wartości godziwej.

- CHF (źródło: nbp.pl) - kurs średni CHF/PLN.

- EUR(źródło: nbp.pl) - kurs średni EUR/PLN.

- USD(źródło: nbp.pl) - kurs średni USD/PLN.

- LIBOR (źródło: stooq.pl) - stawka referencyjna LIBOR 3M dla CHF.

- Wzrost gospodarczy (źródło: GUS) - stopa wzrostu gospodarczego w Polsce. 
- Bezrobocie (źródło: GUS) - stopa bezrobocia w Polsce.

- Inflacja (źródło: GUS) - wskaźnik cen towarów i usług konsumpcyjnych.

Analizowane dane pochodzące ze sprawozdań KNF zostały uśrednione do kwartałów, ponieważ w raportach są przedstawiane w częstotliwości miesięcznej. Wszystkie dane natomiast ze względu na możliwość występowania zależności sezonowych zostały odsezonowane za pomocą procedury Tramo/Seats ${ }^{1}$.

Wybrane dane zostały poddane analizie statystycznej. Podstawowe statystyki opisowe znajdują się w tabeli 1. Minimalna wartość NPL wyniosła 3,03\%, zaś maksymalnie w okresie analizy wynosiła 4,46\%. Wzrost gospodarczy cechował się wysoką zmiennością, ponieważ najmniejsza wartość wynosiła -8,4\%, zaś najwyższy zanotowany wzrost wyniósł 5,5\%. Stopa bezrobocia natomiast sukcesywnie zmniejszała się, a jej najmniejsza wartość wyniosła 5,0569\%. Poziom inflacji wahał się między $-1,5 \%$, a 4,6\%, natomiast dużą zmiennością cechował się poziom kredytów, bo wzrósł od 14,08 mln do 2.403,98 mln. Znaczną zmiennością również cechował się kurs CHF/PLN, ponieważ wzrósł od 3,101 CHF/PLN do 4,2477 CHF/PLN, Stawka LIBOR 3M dla CHF natomiast sukcesywnie zmniejszała się z poziomu $0,0018 \%$ do $-0,0081 \%$. Kurs USD/PLN również zwiększył się z poziomu 2,7490 USD/PLN do 4,0966 USD/PLN, tak jak kurs EUR/PLN, który najmniejszą swoją wartość odnotował na poziomie 3,9483 EUR/PLN, zaś największą na poziomie 4,5066 EUR/PLN.

Tabela 1. Statystyki opisowe

\begin{tabular}{|c|c|c|c|c|c|}
\hline & Minimum & Maksimum & Średnia & $\begin{array}{c}\text { Błąd } \\
\text { standardowy }\end{array}$ & $\begin{array}{c}\text { Odchylenie } \\
\text { standardowe }\end{array}$ \\
\hline NPL & 0,0303 & 0,0446 & 0,0373 & 0,0006 & 0,0035 \\
\hline $\begin{array}{c}\text { Wzrost } \\
\text { gospodarczy }\end{array}$ & $-8,4000$ & 5,5000 & 3,2684 & 0,4070 & 2,5091 \\
\hline Bezrobocie & 5,0569 & 13,5579 & 9,5894 & 0,4970 & 3,0635 \\
\hline Inflacja & 98,5000 & 104,6000 & 101,6000 & 0,2967 & 1,8289 \\
\hline Kredyty & $14,08 \mathrm{mln}$ & $2403,98 \mathrm{mln}$ & $692,15 \mathrm{mln}$ & $117435,72 \mathrm{mln}$ & $723,92 \mathrm{mln}$ \\
\hline CHF & 3,1017 & 4,2477 & 3,6887 & 0,0446 & 0,2751 \\
\hline LIBOR & $-0,0081$ & 0,0018 & $-0,0038$ & 0,0007 & 0,0040 \\
\hline USD & 2,7490 & 4,0966 & 3,5244 & 0,0612 & 0,3770 \\
\hline EUR & 3,9483 & 4,5066 & 4,2376 & 0,0180 & 0,1111 \\
\hline
\end{tabular}

Źródło: opracowanie własne.

\footnotetext{
${ }^{1}$ Za pomocą JDemetra+. Wyniki testów wg p-value były ocenione jako dobre.
} 
Tabela 2. Korelacja Pearsona i poziom istotności (dwustronna)

\begin{tabular}{|c|c|c|c|c|c|c|c|c|}
\hline & NPL & $\begin{array}{c}\text { Wzrost } \\
\text { gospo- } \\
\text { darczy }\end{array}$ & $\begin{array}{c}\text { Bezro- } \\
\text { bocie }\end{array}$ & Inflacja & Kredyty & CHF & LIBOR & USD \\
\hline NPL & 1,000 & $-0,142$ & 0,161 & $0,390^{*}$ & $0,460^{* *}$ & $-0,506 * *$ & $0,406^{*}$ & $-0,494 * *$ \\
\hline Istotność & & 0,394 & 0,335 & 0,016 & 0,004 & 0,001 & 0,012 & 0,002 \\
\hline $\begin{array}{c}\text { Wzrost } \\
\text { gospodar- } \\
\text { czy }\end{array}$ & $-0,142$ & 1,000 & $-0,221$ & $-0,109$ & $-0,097$ & $-0,094$ & $-0,216$ & $-0,025$ \\
\hline Istotność & 0,394 & & 0,183 & 0,514 & 0,561 & 0,573 & 0,192 & 0,880 \\
\hline $\begin{array}{c}\text { Bezrobo- } \\
\text { cie }\end{array}$ & 0,161 & $-0,221$ & 1,000 & $-0,023$ & $-0,540 * *$ & $-0,697 * *$ & $0,873 * *$ & $-0,772 * *$ \\
\hline Istotność & 0,335 & 0,183 & & 0,889 & 0,000 & 0,000 & 0,000 & 0,000 \\
\hline Inflacja & $0,390^{*}$ & $-0,109$ & $-0,023$ & 1,000 & 0,270 & $-0,299$ & 0,290 & $-0,294$ \\
\hline Istotność & 0,016 & 0,514 & 0,889 & & 0,101 & 0,068 & 0,077 & 0,073 \\
\hline Kredyty & $0,460 * *$ & $-0,097$ & $-0,540^{* *}$ & 0,270 & 1,000 & 0,252 & $-0,277$ & 0,282 \\
\hline Istotność & 0,004 & 0,561 & 0,000 & 0,101 & & 0,128 & 0,092 & 0,087 \\
\hline CHF & $-0,506 * *$ & $-0,094$ & $-0,697 * *$ & $-0,299$ & 0,252 & 1,000 & $-0,825 * *$ & $0,956^{* *}$ \\
\hline Istotność & 0,001 & 0,573 & 0,000 & 0,068 & 0,128 & & 0,000 & 0,000 \\
\hline LIBOR & $0,406^{*}$ & $-0,216$ & $0,873 * *$ & 0,290 & $-0,277$ & $-0,825 * *$ & 1,000 & $-0,876^{* *}$ \\
\hline Istotność & 0,012 & 0,192 & 0,000 & 0,077 & 0,092 & 0,000 & & 0,000 \\
\hline USD & $-0,494 * *$ & $-0,025$ & $-0,772 * *$ & $-0,294$ & 0,282 & $0,956 * *$ & $-0,876^{* *}$ & 1,000 \\
\hline Istotność & 0,002 & 0,880 & 0,000 & 0,073 & 0,087 & 0,000 & 0,000 & \\
\hline EUR & $-0,263$ & $-0,219$ & $-0,536 * *$ & $-0,094$ & 0,279 & $0,736 * *$ & $-0,540 * *$ & $0,733^{* * *}$ \\
\hline Istotność & 0,111 & 0,187 & 0,001 & 0,575 & 0,090 & 0,000 & 0,000 & 0,000 \\
\hline
\end{tabular}

Źródło: opracowanie własne. W tabeli podano poziomy istotności dla parametrów: $* * *-\mathrm{p}<0,01, * *-\mathrm{p}<0,05, *-\mathrm{p}<0,1$.

Z punktu widzenia postawionych hipotez badawczych szczególnie istotne są wartości współczynnika korelacji Pearsona wybranych zmiennych ze wskaźnikiem NPL. Na podstawie danych zamieszczonych w tabeli 2 można wskazać, że wskaźnik NPL nie był skorelowany w sposób istotny statystycznie ze wzrostem gospodarczym, stopą bezrobocia i kursem EUR/PLN. Korelacja miary ryzyka kredytowego ze stopą inflacji jest dodatnia i istotna statystycznie, co oznacza, że 
wzrost stopy inflacji wiązał się ze wzrostem wskaźnika NPL, zatem w analizowanym okresie wzrost inflacji wiązał się ze zmniejszeniem się realnego dochodu społeczeństwa, co w konsekwencji prowadziło do obniżenia zdolności kredytowej ludności. Korelacja inflacji ze wskaźnikiem NPL może być dodatnia jak i ujemna w zależności od warunków ekonomicznych panujących w kraju. Podobną zależność można wskazać dla kursów walut. Wskaźnik korelacji dla kursów CHF/PLN i USD/PLN z miarą ryzyka kredytowego jest ujemny, co oznacza, że wzrost kursu tych walut obcych wiązał się ze spadkiem ryzyka kredytowego. Natomiast stawka referencyjna LIBOR 3M dla CHF jest skorelowana dodatnio z NPL, co wskazuje na wzrost ryzyka kredytowego wraz ze wzrostem tej stopy oprocentowania. Zmienna mierząca poziom kredytów i pożyczek w sektorze finansowym jest pozytywnie skorelowana z NPL, ponieważ na ogół większa wartość kredytów wiązała się z większym ryzykiem kredytowym (dynamika wolumenu NPL była większa niż dynamika wolumenu kredytów ogółem).

\section{WYNIKI ANALIZY}

Za pomocą estymatora KMNK zbudowano modele ekonometryczne opisujące zmienność wskaźnika NPL. Modele uwzględniają podstawowe zmienne kontrolne o charakterze makroekonomicznym (wzrost gospodarczy, stopa bezrobocia i poziom inflacji) oraz mikroekonomicznym (wartość kredytów udzielonych w sektorze finansowym), a także zmiennych opisujących zmienność walut obcych (CHF, USD i EUR) i stawki referencyjnej odpowiedniej dla kredytów z kapitałem wyrażonym w CHF, czyli stawki LIBOR 3M dla CHF. Wyniki estymacji pozwalającej zweryfikować hipotezę pierwszą zamieszczono w tabeli 3, zaś wyniki dla modeli pozwalających na weryfikację hipotezy badawczej nr 2 zostały przedstawione w tabeli 4. Modele 1 i 2 poza podstawowymi zmiennymi kontrolnymi i opóźnioną zmienną objaśnianą o 1 kwartał pozwalają zweryfikować wpływ kursu franka szwajcarskiego na ryzyko kredytowe w Polsce. W obydwu przypadkach wpływ ten jest istotny statystycznie i ujemny, co oznacza, że wzrost kursu tej waluty powodował zmniejszenie się ryzyka kredytowego. Ze względu na duże zainteresowanie tematem kredytów w CHF i ich skutków dla systemu bankowego zbadano także oddziaływanie stawki referencyjnej LIBOR 3M dla CHF, która to nie miała istotnego statystycznie oddziaływania na ryzyko kredytowe. Na podstawie modelu 1 i 2 możliwe jest stwierdzenie, że pierwsza hipoteza badawcza została zweryfikowana. 
Tabela 3. Wyniki analizy ekonometrycznej

\begin{tabular}{|c|c|c|c|c|}
\hline \multirow[t]{2}{*}{ Nazwa zmiennej } & \multicolumn{2}{|c|}{ Model 1} & \multicolumn{2}{|c|}{ Model 2} \\
\hline & Współczynnik & p-value & Współczynnik & $\mathrm{p}$-value \\
\hline const & 0,1029 & $0,0400 * *$ & 0,1059 & $0,0421^{* * *}$ \\
\hline Wzrost gospodarczy & 0,0004 & 0,1559 & 0,0005 & 0,1659 \\
\hline Kredyty & 0,0000 & $0,0080 * * *$ & 0,0000 & $0,0118 * *$ \\
\hline Inflacja & $-0,0005$ & 0,1506 & $-0,0005$ & 0,1354 \\
\hline d_Bezrobocie & 0,0068 & $0,0448 * *$ & 0,0073 & $0,0522 *$ \\
\hline $\mathrm{CHF}$ & $-0,0075$ & $0,0271 * *$ & $-0,0065$ & $0,0053 * * *$ \\
\hline LIBORCHF & $-0,1086$ & 0,4493 & & \\
\hline $\operatorname{NPL}(\mathrm{t}-1)$ & 0,2932 & 0,1807 & 0,2545 & 0,3069 \\
\hline R kwadrat & \multicolumn{2}{|c|}{0,76} & \multicolumn{2}{|c|}{0,76} \\
\hline F (p-value) & \multicolumn{2}{|c|}{$105,44(0,00)$} & \multicolumn{2}{|c|}{$103,69(0,00)$} \\
\hline $\mathrm{D}-\mathrm{W}$ & \multicolumn{2}{|c|}{1,88} & \multicolumn{2}{|c|}{1,81} \\
\hline
\end{tabular}

Źródło: opracowanie własne.

Tabela 4. Wyniki analizy ekonometrycznej

\begin{tabular}{|c|c|c|c|c|}
\hline \multirow[t]{2}{*}{ Nazwa zmiennej } & \multicolumn{2}{|c|}{ Model 3} & \multicolumn{2}{|c|}{ Model 4} \\
\hline & Współczynnik & p-value & Współczynnik & p-value \\
\hline const & 0,1074 & $0,0370 * *$ & 0,0945 & 0,1166 \\
\hline $\begin{array}{l}\text { Wzrost gospodar- } \\
\text { czy }\end{array}$ & 0,0006 & 0,1159 & 0,0005 & 0,2075 \\
\hline Kredyty & 0,0000 & $0,0124 * *$ & 0,0000 & $0,0889 *$ \\
\hline Inflacja & $-0,0006$ & $0,0974 *$ & $-0,0004$ & 0,2986 \\
\hline$\Delta$ Bezrobocie & 0,0079 & $0,0374 * *$ & 0,0073 & $0,0958^{*}$ \\
\hline USD & $-0,0049$ & $0,0063 * * *$ & & \\
\hline EUR & & & $-0,0094$ & $0,0489 * *$ \\
\hline NPL $(t-1)$ & 0,2310 & 0,3442 & 0,4885 & $0,0446 * *$ \\
\hline R kwadrat & \multicolumn{2}{|c|}{0,76} & \multicolumn{2}{|c|}{0,71} \\
\hline $\mathrm{F}$ (p-value) & \multicolumn{2}{|c|}{$29,00(0,00)$} & \multicolumn{2}{|c|}{$32,28(0,00)$} \\
\hline $\mathrm{D}-\mathrm{W}$ & \multicolumn{2}{|c|}{1,66} & \multicolumn{2}{|c|}{1,71} \\
\hline
\end{tabular}

Źródło: opracowanie własne. 
Modele 3 i 4 przedstawione w tabeli 4 umożliwiają zweryfikowanie drugiej hipotezy badawczej. Wpływ zmienności kursu USD/PLN i EUR/PLN jest istotny statystycznie i ujemny. Oznacza to, że wzrost kursu dolara amerykańskiego lub euro powodował obniżenie się wartości wskaźnika NPL. Zatem można stwierdzić, że druga hipoteza badawcza również została zweryfikowana.

Dodatkowo można zauważyć, że wpływ wzrostu gospodarczego na zmienną objaśnianą nie miał w żadnym z modeli istotnego statystycznie wpływu. Oddziaływanie wartości kredytów i pożyczek udzielonych w sektorze finansowym, mimo że było istotne w sensie statystycznym, to jednak współczynnik odpowiadający zmiennej „Kredyt” był bliski 0,00. Zmienną tą wprowadzono do modeli ze względu na znaczną poprawę statystyki Durbina-Watsona dla tych modeli. Wpływ inflacji na NPL był istotny statystycznie tylko dla modelu 3, gdzie współczynnik okazał się być ujemny. Sytuację tą można wythumaczyć faktem, iż w analizowanym okresie wzrostowi inflacji towarzyszył także wzrost średniej pensji w Polsce, dlatego realna wartość niespłaconych kredytów i pożyczek malała w wyniku inflacji, lecz realne dochody kredytobiorców nie zmniejszały się. W takiej sytuacji może dojść do negatywnego oddziaływania stopy inflacji na ryzyko kredytowe (analogicznie jak Szarowska, 2008: 24). Natomiast wzrost stopy bezrobocia powodował wzrost ryzyka kredytowego, a zależność ta była istotna statystycznie.

Modele ekonometryczne od 1 do 4 cechują się dobrym objaśnieniem zmienności ryzyka kredytowego na co wskazuje wysoka wartość współczynnika determinacji R-kwadrat. Wartości statystyki $\mathrm{F}$ pozwalają przypuszczać, że dobór zmiennych w modelach jest prawidłowy. Natomiast wartości statystyk DurbinaWatsona pozwalają wskazać, że autokorelacji reszt w modelach nie ma lub nie można wskazać na występowanie autokorelacji, ponieważ wartości statystyki mieszczą się w obszarze niekonkluzywności, który przyjmuje przedział od 1,15 do 1,86 .

\section{DYSKUSJA I PODSUMOWANIE}

Powyższa analiza literatury i badania empiryczne pozwalają na sformułowanie kilku konkluzji w zakresie makroekonomicznych determinant ryzyka kredytowego sektora bankowego w Polsce. Wzrost wartości kredytów udzielonych dla sektora finansowego może prowadzić do zwiększenia się wskaźnika NPL, wtedy wzrost wolumenu kredytów zagrożonych utratą wartości jest większy niż wzrost wolumenu ogółu udzielonych kredytów. Wzrost gospodarczy okazał się nie mieć istotnego statystycznie wpływu na ryzyko kredytowe, co jest wynikiem analogicznym do badań przeprowadzonych na danych dla państw nadbałtyckich (Łotwy, 
Litwy i Estonii) przez Novikov (2012: 113-127). Wzrost stopy bezrobocia prowadzi do zwiększenia się wskaźnika NPL. Natomiast wpływ inflacji okazał się istotny tylko w przypadku modelu 3, przy czym zależność okazała się ujemna. Oznacza to, że wzrostowi inflacji w badanym okresie towarzyszył wzrost realnych dochodów społeczeństwa, co przełożyło się na utrzymanie zdolności do terminowego spłacania zobowiązań ludności.

Wpływ kursów wybranych walut na wskaźnik NPL oddziaływał istotnie, a zależność ta była ujemna. Można zatem stwierdzić, że hipotezy badawcze zostały zweryfikowane. Sytuacja ta oznacza, że wzrostowi kursów CHF/PLN, USD/PLN i EUR/PLN towarzyszył spadek wartości wskaźnika NPL. Zmienność kursów walut obcych nie wpłynęła znacząco na ryzyko kredytowe w analizowanym okresie z różnych przyczyn. Po pierwsze należy zauważyć, że kredyty walutowe nie stanowią głównej części portfela kredytowego Polaków. Po drugie zdolność do regulowania zobowiązań kredytobiorców kredytów walutowych była na tyle duża, że wzrost kursu walutowego nie spowodował problemów z bieżącym regulowaniem zobowiązań. Można zwrócić uwagę na udział kredytów hipotecznych w CHF w portfelu kredytów o wartości bilansowej brutto powyżej 500 tys. PLN, ponieważ kredyty te stanowiły $28 \%$ portfela wszystkich mieszkaniowych kredytów w CHF (dla portfela kredytów w PLN kredytów powyżej 500 tys. PLN było zaledwie 11\%) na koniec 2019 r. (Raport KNF z 06.2020 r.: 43). Po trzecie, „Rekomendacja S” wymusiła na bankach wstrzymanie sprzedaży kredytów walutowych, jeśli klient nie posiada dochodów w danej walucie. Sytuacja ta doprowadziła, do znacznego ograniczenia akcji kredytowej w walutach obcych, zaś wzrósł wolumen kredytów w PLN.

Na podstawie powyższego badania możliwe jest określenie jaki wpływ miały główne zmienne makroekonomiczne na poziom ryzyka kredytowego w sektorze bankowym w Polsce. Szczególną uwagę poświecono oddziaływaniu zmienności głównych walut obcych na wskaźnik NPL. Wyniki pozwalają na wskazanie, że wpływ ten może być dodatni lub ujemny w zależności od otoczenia makroekonomicznego wpływającego na zdolność bieżącego regulowania zobowiązań przez kredytobiorców. Możliwe jest wskazanie dalszych kierunków badań poprzez poszerzenie analizy o kolejne zmienne makroekonomiczne i zbadanie hierarchizacji oddziaływania tych czynników na ryzyko kredytowe w Polsce.

\section{BIBLIOGRAFIA}

Beck, R., Jakubik, P. and Piloiu, A. (2013). Non-performing loans: What matters in addition to the economic cycle? ECB Working Paper Series, 1515.

Breeden, J.L., Thomas, L. (2008). The relationship between default and economic cycles for retail portfolios across countries: Identifying the drivers of economic downturn. Journal of Risk Model Validation, 2(3). 
Castro, V. (2013). Macroeconomic determinants of the credit risk in the banking system: The case of the GIPSI. Economic Modelling, 31.

Ćurak, M., Pepur, S. and Poposki, K. (2013). Determinants of non-performing loans - evidence from Southeastern European banking systems. Banks and Bank Systems, 8(1).

Klein, N. (2013). Non-Performing Loans in CESEE: Determinants and Impact on Macroeconomic Performance. IMF Working Papers, 13(72).

KNF, https://www.knf.gov.pl/publikacje_i_opracowania/dane_statystyczne [dostęp 26.12.2020].

Nkusu, M. (2011). Nonperforming loans and macrofinancial vulnerabilities in advanced economies. IMF Working Papers, 161.

Novikov, I. (2012). The Empirical Estimation of the Influence of Credit Risk Determinants in Baltic States' Banking Sector. Journal of Modern Accounting and Auditing, 8(1).

Raport Komisji Nadzoru Finansowego z 06.2020 r., Informacja na temat sytuacji sektora bankowego, https://www.knf.gov.pl/knf/pl/komponenty/img/Informacja_na_temat_sytuacji_sektora_bankowego_w_2019_r.pdf [dostęp 30.12.2020].

Szarowska, I. (2018). Effect of macroeconomic determinants on non-performing loans in Central and Eastern European countries. International Journal of Monetary Economics and Finance, 11(1).

Sztaudynger, M. (2018). Czynniki makroekonomiczne a spłacalność kredytów konsumpcyjnych. Gospodarka Narodowa, 296(4).

Zeman, J. and Jurca, P. (2008). Macro Stress Testing of the Slovak Banking Sector. National Bank of Slovak Working Paper, 1, 1-26. 